mgr inż. Dorota Wandzich ${ }^{1}$

dr hab. Grażyna Płaza ${ }^{1}$

Przyjęty/Accepted/Принята: 02.02.2015;

Zrecenzowany/Reviewed/Рецензирована: 09.06.2015;

Opublikowany/Published/Опубликована: 31.12.2015;

\title{
Ocena stanu bezpieczeństwa pracy w oparciu o analizę wypadkowości bezwzględnej i rodzajowej w zakładzie tworzyw sztucznych i materiałów wybuchowych ${ }^{2}$
}

\author{
Safety at Work Assessment Based on an Analysis of Severity and Nature of Accidents \\ in a Plastics and Explosives Production Plant
}

\section{Оценка уровня безопасности труда на заводе искусственных и взрывчатых материалов на основе анализа тяжести и типов несчастных случаев}

\begin{abstract}
A B S T R A K T
Cel: Ocena stanu bezpieczeństwa pracy w zakładzie zajmującym się produkcją tworzyw sztucznych i materiałów wybuchowych. Wprowadzenie: Wypadki przy pracy, jako nagłe wydarzenie związane z pracą, wywołane przyczyną zewnętrzną i prowadzące do urazów lub utraty życia stanowią z globalnego punktu widzenia poważny problem zdrowotny oraz ekonomiczny. Na całym świecie w wypadkach przy pracy ginie rocznie kilkaset tysięcy osób, a wiele milionów ludzi staje się w ich następstwie niepełnosprawnymi. W Polsce rocznie zdarza się kilkadziesiąt tysięcy wypadków przy pracy, w których ginie około tysiąca osób (dane GUS - 2014).

Jedną z najniebezpieczniejszych gałęzi przemysłu, związanych z nieodłącznym ryzykiem, niosącą ze sobą wiele zagrożeń jest produkcja materiałów wybuchowych.

Produkcja, magazynowanie i transport materiałów wybuchowych zawsze były zajęciem niebezpiecznym. W wypadkach, które wydarzyły się podczas tej działalności człowieka zginęły tysiące ludzi, a straty materialne są wręcz niemożliwe do oszacowania. Nieszczęścia, które wydarzyły się podczas produkcji i stosowania materiałów wybuchowych doprowadziły z biegiem czasu do powstania licznych aktów prawnych i innych przepisów mających na celu zminimalizowanie zagrożenia związanego z tymi materiałami zawierających szereg wymagań, które muszą być spełnione podczas produkcji, dystrybucji i stosowania materiałów wybuchowych.

Metodologia: Analiza wypadkowości rodzajowej i bezwzględnej oraz analiza wskaźników wypadków przy pracy.

Wnioski i znaczenie dla praktyki: Badanie i rejestrowanie wypadków przy pracy, analiza ich przyczyn i okoliczności, a także analiza wypadkowości w zakładzie, branży, regionie czy też w skali kraju jest ważnym elementem monitorowania środowiska pracy i ma istotne znaczenie dla prewencji wypadkowej.

W celu poprawy stanu bhp w przedsiębiorstwach, należy wprowadzić usprawnienia organizacyjne takie jak poprawa jakości szkoleń, informowanie pracowników o zagrożeniach i o konieczności stosowania środków ochronnych, rozszerzenie palety stosowanych środków ochronnych, wprowadzenie na terenie zakładu plakatów o tematyce bhp docierających do pracowników i uświadamiających im o konieczności przestrzegania przepisów bhp oraz środków ochrony indywidualnej.
\end{abstract}

Słowa kluczowe: bezpieczeństwo pracy, wypadkowość bezwzględna, wypadkowość rodzajowa, bezpieczeństwo i higiena pracy Typ artykułu: $z$ praktyki dla praktyki

\section{A BSTRACT}

Aim: To assess work safety levels at an industrial plant engaged with the production of plastics and explosives. Introduction: Accidents at work are unexpected incidents occasioned by external causes, giving rise to injury or loss of life. From a global viewpoint, they create a serious health and economic problem. Worldwide, hundreds of thousands people lose their life each year and

Politechnika Śląska, Gliwice / The Silesian University of Technology, Poland; dorota.wandzich@polsl.pl;

Wkład merytoryczny w powstanie artykułu / Percentage contribution: D. Wandzich - 75\%, G. Płaza - 25\%; 
many millions become disabled as a result of accidents at work. In Poland, every year, there are tens of thousands accidents at work where about a thousand people die (Data GUS - 2014). One of the most hazardous industries, associated with an inherent risk of much danger, involves the production of explosives. Production, storage and transportation of explosives was always a hazardous occupation. Accidents associated with these activities culminated in thousands of deaths, but material losses are simply impossible to estimate. Tragedies, which occurred during production and use of explosives gave rise, eventually, to an emergence of many laws and other regulations aimed at minimising dangers associated with such materials. Regulatory documents contain a range of requirements, which must be complied with, during production, distribution and use of explosive substances.

Methodology: Analysis of severity and nature of accidents, and evaluation of accident indicators at work.

Conclusions and relevance for practice: Survey and recording of accidents at work, analysis of causes and circumstances, as well as analysis of accident frequency at individual plants, industry, region and across the entire country, are all important elements of monitoring in the work domain and are essential for prevention of accidents. In order to improve industrial health and safety at work it is necessary to introduce organisational improvements such as improvements to the quality of training, dissemination of information about dangers and need for application of protective measures, expanding the range of protective measures, display of safety posters across the plant and making employees aware of the necessity for compliance with health and safety regulations as well as personal protection measures.

Keywords: safety at work, severity of accident, nature of accident, health and safety at work Type: best practice in action

\section{АННОТАЦИЯ}

Цель: Оценка уровня безопасности труда на заводе с производством искусственных и взрывчатых материалов.

Введение: Несчастные случаи на работе, определяемые как внезапное происшествие связанное с работой, вызванное внешней причиной и вызывающее травмы или смерть, с глобальной точки зрения, являются серьёзной проблемой, связанной со здоровьем и экономикой. Во всем мире каждый год вследствие несчастных случаев гибнет несколько сотен тысяч людей, а многие миллионы становятся инвалидами. В Польше каждый год происходит десятки тысяч несчастных случаев на работе, в результате которых гибнет около тысячи человек (данные ГСУ за 2014 год). Одной из самых опасных отраслей промышленности, неотъемлемо связанной с риском и вызывающей много угроз, является производство взрывчатых веществ. Продукция, хранение и транспортировка взрывчатых веществ всегда были опасным занятием. В происшествиях, которые случились во время этой деятельности погибли тысячи людей, а материальные потери невозможно определить. Несчастья, которые произошли во время производства и применения взрывчатых веществ, привели со временем к появлению множества законов и других нормативных актов, направленных на снижение уровня угрозы, связанной с такими веществами. Данные положения содержат ряд требований, которые должны соблюдаться во время производства, продажи и использования взрывчатых веществ.

Методология: Анализ тяжести и типов несчастных случаев, а также анализ их показателей на производстве.

Выводы и значение для практики: Исследование и регистрирование аварий на производстве, анализ их причин и обстоятельств, а также анализ несчастных случаев на заводе, в отрасли, в области или в глобальном масштабе является важным элементом мониторинга трудовой среды и имеет огромное значение для предупреждения несчастных случаев.

С целью улучшения состояния безопасности труда на предприятиях, следует ввести организационные улучшения, такие как повышение качества обучения, информирование работников об угрозах и необходимости использования защитных средств, расширение гаммы используемых защитных средств, размещение на территории завода постеров на тему охраны труда, которые были бы понятны работникам и помогли бы им понять необходимость соблюдения требований безопасности труда и средств индивидуальной защиты.

Ключевые слова: безопасность труда, анализ тяжести несчастных случаев, анализ типов несчастных случаев, охрана труда Вид статьи: с практики для практики

\section{Wprowadzenie}

„Za wypadek przy pracy uważa się nagłe zdarzenie wywołane przyczyną zewnętrzną powodujące uraz lub śmierć, które nastąpiło w związku z pracą:

- podczas lub w związku z wykonywaną czynnością zwykłą przez pracownika

- wykonywaniem poleceń przełożonych,

- podczas lub w związku z wykonywaniem przez pracownika czynności w interesie zakładu pracy, nawet bez polecenia,

- w czasie pozostawania pracownika w dyspozycji zakładu pracy w drodze między siedzibą zakładu pracy a miejscem wykonywania obowiązku wynikającego ze stosunku pracy" [3].
Aby można było uznać dane zdarzenie za wypadek przy pracy, muszą być spełnione łącznie trzy warunki:

- zdarzenie musi cechować się nagłością,

- zdarzenie musi być spowodowane zadziałaniem czynnika zewnętrznego,

- zdarzenie musi mieć związek z pracą.

Nagłości zdarzenia nie należy rozumieć dosłownie i kwalifikować jako wypadki przy pracy wyłącznie takie zdarzenia, których skutek występuje natychmiast po zadziałaniu jednorazowej przyczyny zewnętrznej.

Przyczyną zewnętrzną zdarzenia może być każdy czynnik zewnętrzny zdolny wywołać w istniejących warunkach negatywne skutki. Pojęcie należy rozumieć bardzo szeroko, a więc nie ograniczać przyczyny zewnętrznej wyłącznie do narzędzi pracy, czy też maszyn i urządzeń 
technologicznych. Przyczyną zewnętrzną może być też sama praca i czynności poszkodowanego lub innej osoby. Aby zakwalifikować zdarzenie jako wypadek przy pracy, nie ma znaczenia zachowanie poszkodowanego pracownika, które przyczyniło się do zaistniałego zdarzenia oraz czy zdarzenie było zawinione, czy niezawinione. Może również mieć miejsce zbieg przyczyn zewnętrznej i wewnętrznej, który doprowadził do zdarzenia. Przepisy nie wymagają, aby przyczyna zewnętrzna była wyłączną przyczyną zdarzenia [1].

Wypadki przy pracy dzielą się na:

- śmiertelne - takie, w wyniku których nastąpiła śmierć w miejscu wypadku lub w okresie nieprzekraczającym 6 miesięcy od dnia wypadku,

- ciężkie - takie, w wyniku których nastąpiło ciężkie uszkodzenie ciała, mianowicie utrata wzroku, słuchu, mowy, zdolności płodzenia lub inne uszkodzenia ciała albo rozstrój zdrowia, naruszające podstawowe funkcje organizmu, a także choroba nieuleczalna lub zagrażająca życiu, trwała choroba psychiczna, trwała całkowita lub znaczna niezdolność do pracy w zawodzie lub trwale poważne zeszpecenie lub zniekształcenie ciała,
- zbiorowe - takie, gdzie w wyniku tego samego zdarzenia wypadkowi uległy co najmniej dwie osoby,

- pozostałe - powodujące inne skutki niż wypadki wymienione wcześniej [3].

Wypadkowość jest to „suma wypadków zaistniałych w określonym czasie, zazwyczaj w ciągu roku, przedstawiona za pomocą wskaźników. Wskaźniki umożliwiają porównywanie, ocenianie i szeregowanie zakładów, branż i państw pod względem wielkości wypadkowości” [1].

Analiza wypadków przy pracy może zostać przeprowadzona w trzech formach:

- analizy bezwzględnej - opartej na porównaniu liczby zdarzeń (liczbie poszkodowanych - wypadek indywidualny i zbiorowy) według ciężkości skutków (wypadki śmiertelne, ciężkie, pozostałe);

- analizy rodzajowej - opartej na porównywaniu zdarzeń według określonych kryteriów m.in. miejsca zdarzenia, charakterystyki poszkodowanego, czasu zdarzenia, przyczyny pośredniej i bezpośredniej zdarzenia;

- analizy wskaźnikowej - opartej na porównaniu zdarzeń według określonych wskaźników charakteryzujących badane zjawiska, np. wskaźniki struktury, natężenia, dynamiki.

\section{Analiza wypadkowości bezwzględnej}

\subsection{Podział wypadków}

Tabela 1. Wypadki zaistniałe w zakładzie tworzyw sztucznych w latach 2010-2014

Table 1. Accidents in a factory manufacturing plastics in the period 2010-2014

\begin{tabular}{|l|c|c|c|c|c|c|}
\hline $\begin{array}{c}\text { Wypadki } \\
\text { Accidents }\end{array}$ & $\mathbf{2 0 1 0}$ & $\mathbf{2 0 1 1}$ & $\mathbf{2 0 1 2}$ & $\mathbf{2 0 1 3}$ & $\mathbf{2 0 1 4}$ & $\begin{array}{c}\text { Suma wypadków } \\
\text { Total }\end{array}$ \\
\hline Śmiertelne / Fatal & 0 & 2 & 0 & 0 & 0 & 2 \\
\hline Ciężkie / Severe & 0 & 1 & 0 & 0 & 6 & 7 \\
\hline Lekkie / Light & 18 & 13 & 22 & 13 & 16 & 82 \\
\hline Razem / Total & 18 & 16 & 22 & 13 & 22 & 91 \\
\hline
\end{tabular}

Źródło: Opracowanie własne.

Source: Own elaboration.

Najwięcej wypadków miało miejsce w latach 2012 i 2014. W analizowanych latach przeważają wypadki lekkie. W 2011 roku wystąpił spadek ogólnej liczby wypadków w stosunku do 2012 r. o 2 wypadki, lecz zaobserwowano wzrost ich ciężkości oraz nieznaczny wzrost liczby dni niezdolności do pracy związanych z wypadkami (dwa wypadki śmiertelne i jeden ciężki). Przyczyną wypadków śmiertelnych była obsługa nabojarki Niepmann. W 2012 roku stwierdzono wzrost ogólnej liczby wypadków w stosunku do 2011 r. o 6 zdarzeń (z 16 w 2011 r. do 22 w 2012 r.) oraz wzrost liczby dni niezdolności do pracy związanych z wypadkami o blisko $80 \%$. W 2013 roku miało miejsce zmniejszenie ogólnej liczby wypadków w stosunku do 2012 r. o 9 wypadków oraz zmniejszenie liczby dni niezdolności do pracy związanych z wypadkami o blisko 70\%. W 2014 roku nastąpił wzrost wypadków o 9 w stosunku do 2013 roku, co jest związane ze zmianami organizacyjnymi oraz zwiększeniem produkcji. 


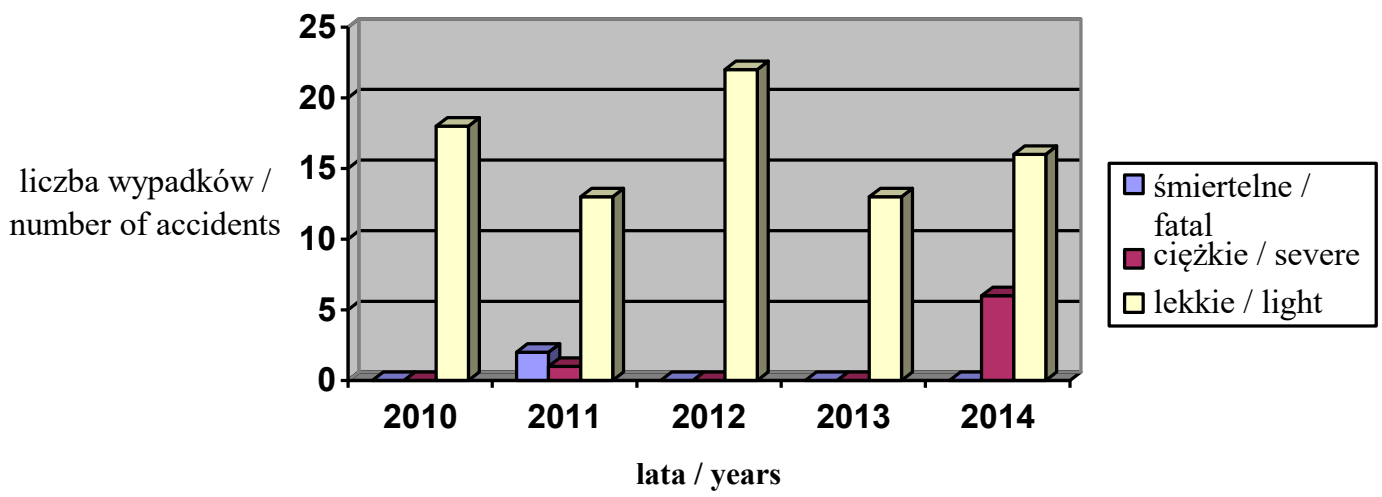

Ryc. 1. Wykres wypadków za okres 2010-2014

Fig. 1. Chart of accidents for the period 2010 to 2014

Źródło: Opracowanie własne.

Source: Own elaboration.

\subsection{Występowanie wypadków $w$ poszczególnych miesiącach w latach 2010-2014}

Tabela 2. Występowanie wypadków w poszczególnych miesiącach

Table 2. Monthly accidents

\begin{tabular}{|l|c|c|c|c|c|c|}
\hline \multicolumn{1}{|c|}{ Miesiąc / Month } & $\mathbf{2 0 1 0}$ & $\mathbf{2 0 1 1}$ & $\mathbf{2 0 1 2}$ & $\mathbf{2 0 1 3}$ & $\mathbf{2 0 1 4}$ & Razem w miesiącach / Total \\
\hline Styczeń, January & 2 & 2 & 1 & 1 & 1 & 7 \\
\hline Luty, February & - & - & 1 & - & 2 & 3 \\
\hline Marzec, March & - & - & 1 & 3 & 3 & 7 \\
\hline Kwiecień, April & - & 1 & 1 & 1 & - & 3 \\
\hline Maj, May & 3 & 1 & - & 3 & - & 7 \\
\hline Czerwiec, June & 1 & 2 & 1 & 2 & - & 28 \\
\hline Lipiec, July & 6 & 1 & 13 & 2 & 6 & 7 \\
\hline Sierpień, August & 3 & 1 & 1 & - & 2 & 8 \\
\hline Wrzesień, September & 1 & - & 1 & 1 & 3 & 2 \\
\hline Październik, October & 1 & 4 & 1 & - & 2 & 8 \\
\hline Listopad, November & - & 1 & - & - & - & 3 \\
\hline Grudzień, December & 1 & 3 & 1 & - & 3 & \\
\hline Razem / Total & 18 & 16 & 22 & 13 & 22 & \\
\hline
\end{tabular}

Źródło: Opracowanie własne.

Source: Own elaboration.

Analizując lata 2010-2014, można stwierdzić, że najwięcej wypadków miało miejsce w lipcu, a najmniej w listopadzie. Związane jest to z rotacją pracowników oraz urlopami wakacyjnymi.

\subsection{Występowanie wypadków $w$ układzie zmian}

Tabela 3. Wypadki a układ zmian w Zakładzie Tworzyw Sztucznych w latach 2010-2014

Table 3. Accidents and system changes at factory manufacturing plastics in 2010-2014

\begin{tabular}{|l|c|c|c|c|c|c|}
\hline $\begin{array}{c}\text { Zmiana robocza / } \\
\text { Working practice changes }\end{array}$ & $\mathbf{2 0 1 0}$ & $\mathbf{2 0 1 1}$ & $\mathbf{2 0 1 2}$ & $\mathbf{2 0 1 3}$ & $\mathbf{2 0 1 4}$ & $\begin{array}{c}\text { Razem w zmianach roboczych } \\
\text { / Total working practice changes }\end{array}$ \\
\hline I & 8 & 10 & 21 & 8 & 10 & 57 \\
\hline II & 4 & 4 & - & 2 & 2 & 12 \\
\hline III & 6 & 2 & - & 3 & 8 & 19 \\
\hline IV & - & - & 1 & - & 2 & 3 \\
\hline Razem / Total & 18 & 16 & 22 & 13 & 22 & 91 \\
\hline
\end{tabular}

Źródło: Opracowanie własne.

Source: Own elaboration. 
W analizowanych latach 2010-2014 w zakładzie pracy najwięcej wypadków miało miejsce podczas pierwszej zmiany, a najmniej wypadków miało miejsce podczas czwartej zmiany.

\section{Analiza wypadkowości rodzajowej}

Tabela 4. Ocena stanu wypadkowości w zależności od wystąpienia niebezpiecznego zdarzenia dla Zakładu Tworzyw Sztucznych Table 4. Evaluation of accidents, depending on circumstances associated with a hazardous event in a factory manufacturing plastics

\begin{tabular}{|c|c|c|c|c|c|c|}
\hline Wydarzenie powodujące wypadek / Cause of the accident & 2010 & 2011 & 2012 & 2013 & 2014 & Razem / Total \\
\hline Upadek / fall & 3 & 2 & 3 & 3 & 4 & 15 \\
\hline Przygniecenie, crush & 2 & 1 & 3 & 1 & 4 & 10 \\
\hline Uderzenie przez ruchomy obiek / struck by a moving object & 1 & & 1 & & 2 & 4 \\
\hline $\begin{array}{l}\text { Niewłaściwe uchwycenie czynnika materialnego / improper } \\
\text { grasping of materials }\end{array}$ & 3 & & 2 & 3 & 3 & 10 \\
\hline $\begin{array}{l}\text { Zły dobór środków ochrony indywidualnej / improper } \\
\text { selection of personal protective equipment }\end{array}$ & & & 1 & & 1 & 2 \\
\hline $\begin{array}{l}\text { Wykonanie pracy ręcznie zamiast przy użyciu czynnika } \\
\text { materialnego / manual performance of tasks instead of } \\
\text { utilisation of equipment }\end{array}$ & 1 & & & 2 & & 3 \\
\hline Nadmierny wysiłek fizyczny / overexertion & & & & 2 & & 2 \\
\hline Brak osłon osobistych / absence of protective guards & & & & 2 & & 2 \\
\hline Złe dojścia / przejścia / poor access/crossings & & 2 & 1 & & 1 & 4 \\
\hline Niewłaściwe tempo pracy / improper working speed & & 1 & & & & 1 \\
\hline $\begin{array}{l}\text { Ruchome części maszyn i urządzeń / moving parts of } \\
\text { machinery and equipment }\end{array}$ & 1 & & & & 3 & 4 \\
\hline Spadające przedmioty, falling objects & 3 & 2 & 3 & & 1 & 8 \\
\hline Nieodpowiedni czynnik materialny / unsuitable materials & & 2 & & & & 2 \\
\hline $\begin{array}{l}\text { Uderzenie, przygniecenie człowieka przez czynnik materialny } \\
\text { transportowany mechanicznie lub ręcznie / collision, } \\
\text { crushing of humans by materials transported mechanically or } \\
\text { manualny. }\end{array}$ & 3 & 4 & 5 & & 2 & 14 \\
\hline $\begin{array}{l}\text { Chwycenie człowieka przez maszyny lub ich części, } \\
\text { urządzenia i środki transportu / seizure of humans by } \\
\text { machines or their working parts, equipment and vehicles. }\end{array}$ & 2 & 2 & 3 & & 1 & 8 \\
\hline
\end{tabular}

Źródło: Opracowanie własne.

Source: Own elaboration.

W powyższym zestawieniu przedstawiono wydarzenia bezpośrednio powodujące obrażenia fizyczne, najczęstsze przyczyny wypadków przy pracy oraz skutki wypadków przy pracy w analizowanych latach 2010-2014 w badanym zakładzie pracy.

W 2010 roku najczęściej dochodziło do wypadków na stanowiskach pracy w Oddziale Produkcji MW Nitroglicerynowych. Wypadki te wynikały z niewłaściwego uchwycenia czynnika materialnego, upadku, poślizgnięcia czy też uderzenie lub potrącenia przez spadający lub transportowany czynnik materialny. Skutkami były: skaleczenia i urazy kończyn dolnych i górnych. W 2011 roku najwięcej wypadków odnotowano w Oddziale Produkcji MW Nitroglicerynowych oraz w Zakładzie Wyrobów Tworzyw Sztucznych. Najczęstsze skutki tych wypadków to urazy kończyn dolnych i górnych oraz głowy, amputacje częściowe części kończyn górnych. W 2012 roku w Zakładzie Produkcji Nitrogliceryny miał miejsce wybuch (produkcja nitroestrów), skutkiem tego zdarzenia był wypadek zbiorowy i 21 poszkodowanych (urazy kończyn górnych i dolnych, poparzenia, urazy akustyczne i ciśnieniowe oraz reakcja na stres). 


\subsection{Ocena stanu wypadkowości według wieku i stażu pracowników}

Tabela 5. Podział wypadków według wieku poszkodowanych

Table 5. Classification of accidents by victim age

\begin{tabular}{|c|c|c|c|c|c|c|}
\hline $\begin{array}{c}\text { Wiek poszkodowanych } \\
\text { Age of the victims (years) }\end{array}$ & $\mathbf{2 0 1 0}$ & $\mathbf{2 0 1 1}$ & $\mathbf{2 0 1 2}$ & $\mathbf{2 0 1 3}$ & $\mathbf{2 0 1 4}$ & $\begin{array}{c}\text { Razem / } \\
\text { Total }\end{array}$ \\
\hline 21-30 lat & 3 & 0 & 1 & 0 & 0 & 4 \\
\hline 31-40 lat & 3 & 7 & 12 & 5 & 8 & 35 \\
\hline $41-50$ lat & 10 & 9 & 7 & 6 & 11 & 43 \\
\hline 51-60 lat & 2 & 0 & 2 & 2 & 3 & 9 \\
\hline
\end{tabular}

Źródło: Opracowanie własne.

Source: Own elaboration.

W analizowanym zakładzie pracy w latach 2010-2014 wypadkom ulegali najczęściej pracownicy w wieku 41-50 lat a najrzadziej w wieku 21-30 i 51-60 lat.

\subsubsection{Struktura wiekowa zatrudnienia}

Tabela 6. Struktura wiekowa zatrudnienia w latach 2010-2014

Table 6. The age structure of employees in the years 2010-2014

\begin{tabular}{|c|c|c|c|c|c|c|}
\hline $\begin{array}{c}\text { Wiek pracowników } \\
\text { Employee age (years) }\end{array}$ & $\mathbf{2 0 1 0}$ & $\mathbf{2 0 1 1}$ & $\mathbf{2 0 1 2}$ & $\mathbf{2 0 1 3}$ & $\mathbf{2 0 1 4}$ & $\begin{array}{c}\text { Razem / } \\
\text { Total }\end{array}$ \\
\hline 21-30 lat & 112 & 307 & 268 & 200 & 195 & 1082 \\
\hline 31-40 lat & 700 & 600 & 500 & 520 & 480 & 2800 \\
\hline $41-50$ lat & 200 & 100 & 200 & 116 & 208 & 824 \\
\hline 51-60 lat & 100 & 90 & 100 & 100 & 98 & 488 \\
\hline Ogołem zatrudnionych / Total employees & 1112 & 1097 & 1068 & 1026 & 981 & 5194 \\
\hline
\end{tabular}

Źródło: Opracowanie własne.

Source: Own elaboration.

Ze struktury wiekowej zatrudnienia w latach 2010-214 wynika, że największą grupę zatrudnionych stanowili pracownicy w wieku 31-40 lat oraz pracownicy w wieku

21-30 lat, natomiast najmniejszą grupę zatrudnionych stanowili pracownicy w wieku 51-60 lat.

\subsubsection{Podział wypadków według stażu pracy}

Tabela 7. Podział wypadków według stażu pracy poszkodowanych

Table 7. Distribution of accidents according to victim's length of employment

\begin{tabular}{|l|c|c|c|c|c|c|}
\hline $\begin{array}{c}\text { Staż pracy poszkodowanych } \\
\text { Victim's length of employment (years) }\end{array}$ & $\mathbf{2 0 1 0}$ & $\mathbf{2 0 1 1}$ & $\mathbf{2 0 1 2}$ & $\mathbf{2 0 1 3}$ & $\mathbf{2 0 1 4}$ & $\begin{array}{c}\text { Razem } \\
\text { Total }\end{array}$ \\
\hline $\begin{array}{l}\text { Mniej niż 10 lat } \\
<10 \text { years }\end{array}$ & 1 & 0 & 3 & 1 & 4 & 9 \\
\hline 10-20 lat & 2 & 7 & 8 & 5 & 5 & 27 \\
\hline $20-30$ lat & 14 & 9 & 10 & 6 & 11 & 50 \\
\hline $\begin{array}{l}\text { Więcej niż 30 lat } \\
>30 \text { years }\end{array}$ & 1 & 0 & 1 & 1 & 3 & 6 \\
\hline
\end{tabular}

Źródło: Opracowanie własne.

Source: Own elaboration.

W latach 2010-2014 najwięcej wypadków było wśród pracowników ze stażem 20-30 lat i pracowników ze stażem
10-20 lat, a najmniej wśród pracowników ze stażem 30 lat i więcej. 


\section{Analiza wskaźników wypadków przy pracy}

Określenie wypadkowości jako wysokiej, średniej lub niskiej dokonywane jest na podstawie analizy zmian wartości wskaźników w rocznych lub kilkuletnich okresach, a także na podstawie porównywania wypadkowości dotyczącej innego przedsiębiorstwa. W tym celu stosuje się wskaźniki częstości wypadków oraz wskaźniki ciężkości wypadków.

$$
W_{Z}=\frac{w}{z} 10^{3}
$$

Gdzie:

$W_{z}$ - Wskaźnik częstości wypadków na 1000 zatrudnionych osób załogi

C - wskaźnik ciężkości wypadków

$$
c=\frac{D s}{w}
$$

Gdzie:

W - liczba wypadków

$z$ - liczba załogi

$D_{s}$ - liczba dniówek straconych wskutek wypadku
W przypadku korzystania ze wskaźników częstości i ciężkości wypadków występuje niedogodność wyrażająca się tym, że obydwa mierniki nie charakteryzują w pełni dynamiki wypadkowości, co wyraża się tym, iż jeden wskaźnik może się zwiększać, podczas gdy jednocześnie drugi się zmniejsza (w porównywalnym okresie czasu).

Niedogodność tę można wyeliminować, stosując uogólniony wskaźnik strat uzyskany w wyniku mnożenia wskaźnika częstości i wskaźnika ciężkości wypadków (w odniesieniu do jednego zatrudnionego) [2].

Gdzie:

$$
W_{u s}=W_{z} \cdot C=\frac{D s}{z}
$$

$W^{*}$ - wskaźnik częstości wypadków w odniesieniu do jednego zatrudnionego

C - wskaźnik ciężkości wypadków

\section{Wskaźnik częstości wypadków na 1000 zatrudnionych osób załogi}

$$
W_{Z}=\frac{w}{z} 10^{3}
$$

Tabela 8. Wskaźnik częstości wypadków.

Table 8. Accident frequency Source: personal elaboration

\begin{tabular}{|l|c|c|c|c|c|}
\hline \multicolumn{1}{|c|}{ Rok, year } & $\mathbf{2 0 1 0}$ & $\mathbf{2 0 1 1}$ & $\mathbf{2 0 1 2}$ & $\mathbf{2 0 1 3}$ & $\mathbf{2 0 1 4}$ \\
\hline Liczba wypadków W / Number of accidents & 18 & 16 & 22 & 13 & 22 \\
\hline Liczba załogi Z / Number of employees & 1112 & 1097 & 1068 & 1026 & 981 \\
\hline Wskaźnik częstości / Frequency index & 16,1 & 14,5 & 20,5 & 12,6 & 22,4 \\
\hline
\end{tabular}

Źródło: Opracowanie własne.

Source: Own elaboration.

Najwięcej wypadków miało miejsce w latach 2012 i 2014. Były to wypadki lekkie. Wtedy tez wystąpił spadek zatrudnienia, dlatego wskaźnik w 2014 roku jest wysoki w stosunku do wcześniejszych lat.

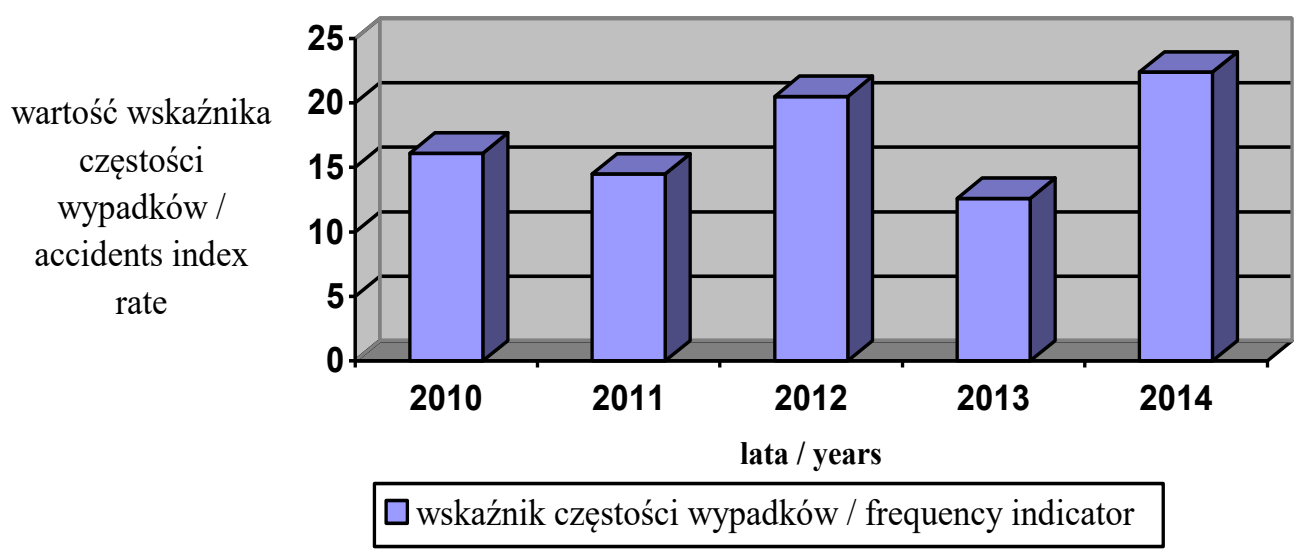

Ryc. 2. Zmiany wskaźnika częstości wypadków w latach 2010-2014

Fig. 2. Changes to the accident frequency indicator for the years 2010-2014

Źródło: Opracowanie własne.

Source: Own elaboration. 
Tabela 9. Wskaźnik ciężkości wypadków

Table 9. Accident severity indicator

\begin{tabular}{|l|c|c|c|c|c|}
\hline \multicolumn{1}{|c|}{ Rok, / Year } & $\mathbf{2 0 1 0}$ & $\mathbf{2 0 1 1}$ & $\mathbf{2 0 1 2}$ & $\mathbf{2 0 1 3}$ & $\mathbf{2 0 1 4}$ \\
\hline Liczba dni niezdolnych do pracy / number of days unit for work & 886 & 1040 & 2002 & 595 & 289 \\
\hline Liczba wypadków / number of accidents & 18 & 16 & 22 & 13 & 22 \\
\hline Wskaźnik ciężkości wypadków / accident severity index & 49,2 & 65,78 & 91,36 & 45,7 & 13,1 \\
\hline
\end{tabular}

Źródło: Opracowanie własne.

Source: Own elaboration.

Najwyższy wskaźnik ciężkości wypadków wystąpił w 2012 roku (największa liczba straconych dniówek

w pracy), a najniższy w 2014 roku (najmniejsza liczba straconych dniówek).

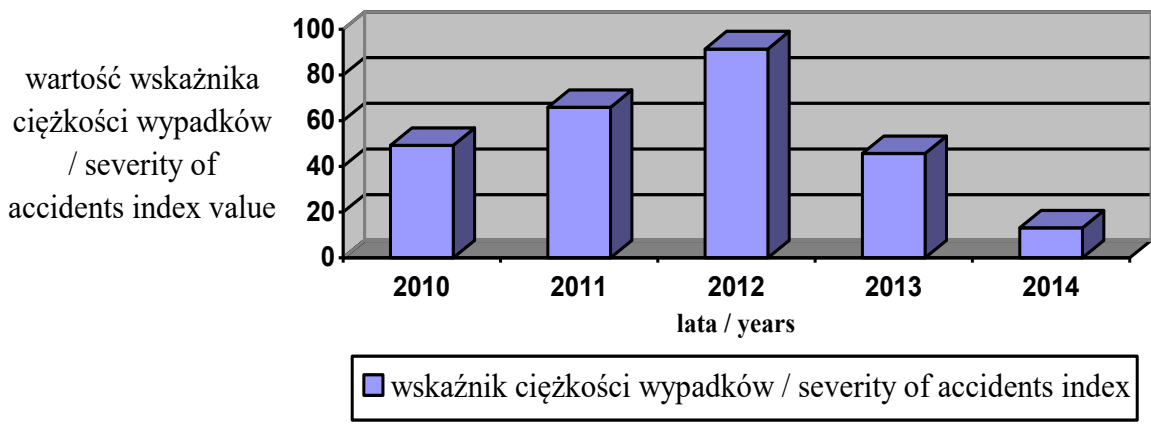

Ryc. 3. Wskaźnik ciężkości wypadków w latach 2010-2014

Fig. 3. Severity of accident index for the years 2010-2014

Źródło: Opracowanie własne.

Source: Own elaboration.

Tabela 10. Uogólniony wskaźnik strat w latach 2010-2014

Table 10. Generalized loss index for the years 2010-2014

\begin{tabular}{|l|c|c|c|c|c|}
\hline \multicolumn{1}{|c|}{ Rok / Year } & $\mathbf{2 0 1 0}$ & $\mathbf{2 0 1 1}$ & $\mathbf{2 0 1 2}$ & $\mathbf{2 0 1 3}$ & $\mathbf{2 0 1 4}$ \\
\hline Liczba dni niezdolnych do pracy Ds / Number of days unfit for work & 886 & 1040 & 2002 & 585 & 289 \\
\hline Liczba załogi Z / Number of employees & 1112 & 1097 & 1068 & 1026 & 981 \\
\hline WUS- uogólniony wskaźnik strat / generalized loss index & 0,7 & 0,9 & 1,8 & 0,5 & 0,3 \\
\hline
\end{tabular}

Źródło: Opracowanie własne.

Source: Own elaboration.

Największy wskaźnik start miał miejsce w 2012 roku - wtedy wystąpiła największa liczba straconych dniówek.
Najniższy wskaźnik obserwujemy w 2014 roku, w którym liczba straconych dniówek była najmniejsza.

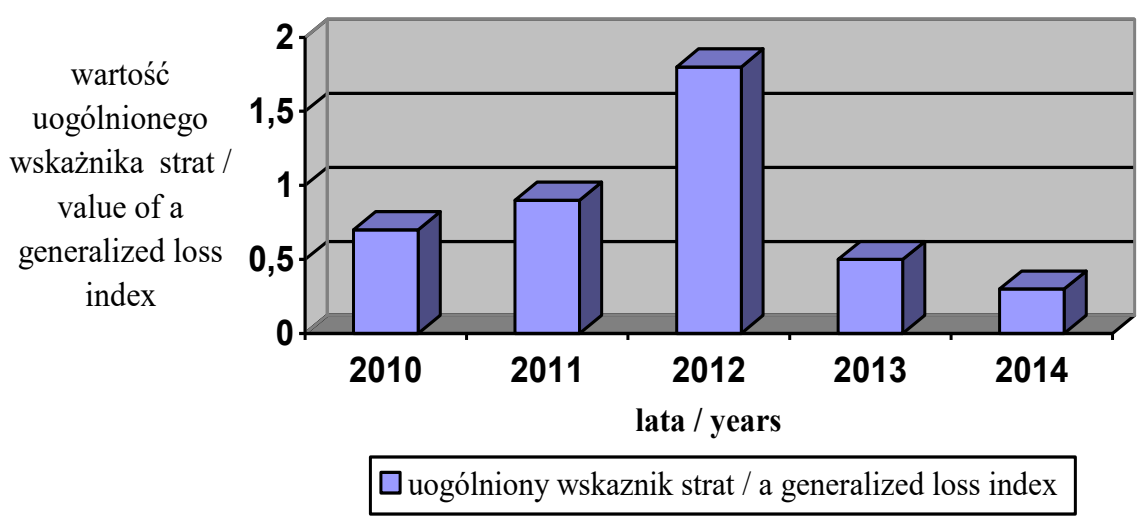

Ryc. 4. Uogólniony wskaźnik strat w latach 2010-2014

Fig. 4. A generalized loss index for the years 2010-2014

Źródło: Opracowanie własne.

Source: Own elaboration. 


\section{Profilaktyka wypadków przy pracy}

Profilaktyka wypadków przy pracy obejmuje szereg działań, których zadaniem jest kształtowanie bezpiecznych i higienicznych warunków pracy [4].

Najczęściej podejmowane w zakładach pracy działania dotyczące profilaktyki wypadków przy pracy to przede wszystkim: szkolenia bhp dla pracowników, próby szacowania ryzyka przy wykonywaniu określonych prac wdrożenia systemu zarządzania bezpieczeństwem w zakładach pracy, bezpośredni nadzór i kontrola nad warunkami pracy, powołanie komisji bezpieczeństwa, występowanie i działalność służb bezpieczeństwa pracy, prowadzenie rejestru dotyczącego wypadków przy pracy, stosowanie przez pracowników sprzętu ochrony indywidualnej oraz zastosowanie na terenie zakładu pracy środków ochrony zbiorowej, prowadzenie działalności propagandowej w postaci plakatów lub ulotek na terenie zakładu pracy, obligowanie pracowników do utrzymania ładu i porządku na stanowiskach pracy.

Środki powszechnie stosowane do promocji bezpieczeństwa pracy to przede wszystkim przepisy regulujące ogólne warunki pracy, projektowanie, budowę, utrzymywanie obiektów budowlanych, stosowanego sprzętu, obowiązki pracodawców i pracowników, szkolenie wstępne i okresowe, badania lekarskie oraz nadzór wynikający z obowiązujących przepisów.

Dużą rolę w promocji bezpiecznej pracy odgrywają badania statystyczne dotyczące: rodzaju wypadków przy pracy, czynności powodujących wypadek przy pracy, częstości wypadków przy pracy, wiek i kwalifikacje pracowników, których dotyczy wypadek przy pracy, najczęstszych przyczyn wypadków przy pracy, wykazów stanowisk, na których najczęściej dochodzi do wypadku.

Kolejny popularnym środkiem promującym bezpieczeństwo pracy jest nauczanie bezpieczeństwa pracy w szkołach wyższych i średnich oraz na kursach przygotowujących do zawodu, a następnie praktyczne szkolenia pracowników w obszarze bezpieczeństwa pracy.

Kolejnym krokiem jest stosowanie zachęt finansowych do popierania przedsięwzięć mających na celu profilaktykę wypadków przy pracy np. zróżnicowanie wysokości składki ubezpieczenia w zależności od kształtowanych w zakładzie pracy warunków bezpieczeństwa i higieny pracy.

\section{Podsumowanie i wnioski}

Wyniki analizy statystycznej karty wypadków w Zakładzie Tworzyw Sztucznych wykazały, że:

- najczęstszymi wydarzeniami bezpośrednio powodującymi obrażenia fizyczne były: zetknięcie się człowieka z ostrymi, szorstkimi czynnikami materialnymi, uderzenie przez spadający czynnik materialny, uderzenie pionowe w nieruchomy obiekt, uwiezienie człowieka pod czynnikiem materialnym, kolizja z poruszającym się obiektem, uderzenie przez ruchomy obiekt;

- najczęstszymi przyczynami wypadku były: niewłaściwe posługiwanie się czynnikiem materialnym, ukryte wady materialne czynnika materialnego, nieznajomość zasad i przepisów bhp, niewłaściwy dobór środków ochrony indywidualnej, niewłaściwe naprawy lub remonty czynnika materialnego, niedostateczne przygotowanie zawodowe pracownika, niewłaściwa ogólna organizacja pracy, niedostateczna koncentracja na wykonywanej pracy, zaskoczenie niespodziewanym zdarzeniem, zakłócenie w procesie technologicznym (wybuch);

- najczęstsze skutki wypadków w analizowanych latach 2010-2014 to: skaleczenia, złamania, zmiażdżenia, amputacje, urazy kończyn górnych i dolnych, oparzenia termiczne i chemiczne, urazy głowy, uraz akustyczny, ciśnieniowy, reakcja na ciężki stres, urazy oczu;

- najczęściej wypadkom w latach 2010-2014 ulegali pracownicy w wieku 41-50 lat;

- najwięcej wypadków było w latach 2012 i 2014 stanowiły wypadki lekkie. Najwyższy wskaźnik ciężkości wypadków zaistniał w 2012 roku, wtedy było najwięcej straconych dniówek w pracy, a najniższy w 2014 roku. Natomiast uogólniony wskaźnik strat najwyższy był w 2012 roku.

W celu poprawy warunków bhp w firmie należy wprowadzić usprawnienia organizacyjne takie jak: poprawa jakości szkoleń, informowanie pracowników o zagrożeniach i o konieczności stosowania środków ochronnych, rozszerzenie palety stosowanych środków ochronnych, wprowadzenie na terenie zakładu plakatów o tematyce bhp docierających do pracowników i uświadamiających im konieczność przestrzegania przepisów bhp oraz środków ochrony indywidualnej, wprowadzenie i rozwój metod systemowego zarządzania bezpieczeństwem i higieną pracy, ze szczególnym uwzględnieniem oceny i ograniczania ryzyka zawodowego. Istotne jest wprowadzenie również innowacyjnych rozwiązań organizacyjnych i technicznych, ukierunkowanych na rozwój zasobów ludzkich oraz nowych wyrobów, technologii, metod i systemów zarządzania, których wykorzystanie przyczyni się do znaczącego ograniczenia liczby osób zatrudnionych w warunkach narażenia na czynniki niebezpieczne, szkodliwe i uciążliwe oraz ograniczenia związanych z nimi wypadków przy pracy, czy nawet chorób zawodowych, a co za tym idzie wynikających strat ekonomicznych i społecznych.

\section{Literatura}

[1] „Ocena zagrożeń w środowisku pracy”, Materiały szkoleniowe, praca zbiorowa, CIOP, Warszawa 1991.

[2] Markowski A.S., Zapobieganie stratom w przemyśle. Część II. Zarzadzanie bezpieczeństwem i higiena pracy, Wydawnictwo Politechniki Łódzkiej, Łódź 1999.
[3] Ustawa z dnia 30 października 2002 r. o ubezpieczeniu społecznym z tytuły wypadków przy pracy i chorób zawodowych (Dz.U. $2009 \mathrm{nr}$ 167, poz. 1322).

[4] Strona internetowa Europejskiiej Agencji Bezpieczeństwa i Zdrowia w Pracy, https://osha.europa.eu/pl/topics/ accident_prevention/index_html, [Dostęp 01.07.2014]. 
mgr inż. Dorota Wandzich - absolwentka Wydziału Górnictwa i Geologii Politechniki Śląskiej, Ukończyła kierunek Zarządzanie i Inżynieria Produkcji ze specjalizacją „Technika i organizacja bezpieczeństwa pracy”. Obecnie doktorantka w Instytucie Inżynierii Produkcji na Wydziale Organizacji i Zarządzania Politechniki Śląskiej.

dr hab. Grażyna Płaza - dyscyplina inżynieria środowiska, specjalizacja: mikrobiologia techniczne. Pracownik naukowy w Instytucie Inżynierii Produkcji Wydziału Organizacji i Zarządzania Politechniki Śląskiej. Zakres tematyczny: ergonomia i higiena przemysłowa, czynniki materiale środowiska pracy, ze szczególnym uwzględnieniem czynników biologicznych, zagadnienia bioprzemysłu i biogospodarki. 